European Journal of Business and Innovation Research

Vol.8, No.4.pp. 16-28, July 2020

Published by ECRTD-UK

Print ISSN: 2053-4019(Print), Online ISSN: 2053-4027(Online)

\title{
FACTORS AFFECTING REAL ESTATE VALUES: A CASE STUDY OF REAL ESTATE IN HO CHI MINH CITY
}

\author{
Tran Trong Khue, Van Lang University (VLU) \\ Mai Thanh Loan, Van Lang University (VLU)
}

\begin{abstract}
Real estate value tends to change continuously over the years. To accurately determine the value of the real estate you target, it is necessary to consider and evaluate based on many different impacts. Demand-supply factor, but the cost of a real estate in the market is also directly affected by factors such as natural element, property location, legal element. Therefore, this paper studied factors affecting real estate values of real estate in Ho Chi Minh City (HCMC). The authors surveyed 500 staffs who are working for real estate companies in HCMC. This paper used a simple random sampling technique, tested Cronbach's Alpha, the exploratory factor analysis, and Structural Equation Modelling (SEM). The paper used a questionnaire on a 5-point Likert scale. This paper found five factors affecting real estate values of real estate in Ho Chi Minh City $(H C M C)$ with a significance level of 0.01 .
\end{abstract}

KEYWORDS: Real estate, values, market, HCMC, and VLU.

\section{INTRODUCTION}

According to the Ho Chi Minh City authorities, the development and functional management of the real estate market will have the effect of promoting economic growth through stimulating measures on land, creating constructions, factories, architectural objects, thereby creating significant and critical structural changes in industries. Besides, the development of the real estate market increases the volume of real estate goods transactions, which is an essential condition for increasing the State budget revenue by collecting taxes related to real estate. Particularly for Ho Chi Minh City real estate market, in recent years, it has attracted the attention of many domestic and foreign investors, becoming a key market of many multinational real estate corporations. The development of the City's real estate market in recent years has contributed to the GDP growth of the City and the GDP of the service sector in particular. According to statistics from the city authorities, the budget revenue from the real estate market is increasing, the annual average is over VND 8,000 billion, accounting for about $10 \%$ of the total budget revenue.

On average, each year, the real estate business contributes about $11 \%$ to the GDP of the service sector, the average growth rate reaches $5 \%$ per year, contributing to the increase in the proportion of GDP in the service sector, accelerating the transition. City economic structure. In the past, when the real estate market has developed, domestic capital and foreign investment capital have been mobilized to participate in construction and real estate business and real estate and peak services. Vietnam joined the WTO with about 148,000 billion in 2008. Of the total capital involved in the real estate market, FDI accounts for over $50 \%$. Above mentioned things the main 
European Journal of Business and Innovation Research

Vol.8, No.4.pp. 16-28, July 2020

Published by ECRTD-UK

Print ISSN: 2053-4019(Print), Online ISSN: 2053-4027(Online)

objective of this article is to find out various factors affecting real estate values of real estate in Ho Chi Minh City (HCMC).

\section{LITERATURE REVIEW}

\section{Real estate values (REV)}

Developed countries define the market value of a real estate is standardized to facilitate research, statistics, management, and sales.

Some developed countries have set uniform standards of Professional Appraisal Practice (USPAP) in which the market value is understood as the most likely price to form an estate. In a competitive and public market under all conditions necessary to fair trade, the buyer and the seller behave cautiously, knowingly, and acknowledge that the price is not affected by outrageous factors. In other words, both the buyer and the seller must have sufficient information and sufficient time to decide on a publicly-traded market. This concept considered synonymous with the value of exchanging in everyday language that is both a buy and sell (Clapp, J.M, 2018).

Another concept of value in the field of real estate is investment value based on parameters or assumptions. To illustrate the importance of investment, we can mention the case of a housing development company involved in upgrading an old villa and apartment area but located in a planned conservation area of historical sites (Yihong, 2016). Business benefits from this project may not be much because the rent is not a worthy reward for the construction cost that this company has spent.

When evaluating insurable value, valuators are often concerned with the estimated cost of rebuilding a building. The insurable value is usually not related to the land plot as it is generally not affected by the arising hazards. Besides, the cost of the appraisal assigned to the property to pay taxes included - the valuation calculated based on market value (Filiz Ersoz, 2018).

\section{Natural factor (NF)}

In terms of long-term value, the natural factor is what investors are most interested in the green environment. In the group of natural factors affecting real estate value, buyers often consider primary factors such as:

Property location: Including relative location and absolute position. Real estate in the center of an urban area, densely populated, is called relative location. Properties located at intersections or intersections on essential roads are called clean places. And of course, the better the location, the better the development potential, the higher the real estate value. Therefore, real estate is relative - absolute value is higher than in other areas (Golob K, 2016).

Area: Depending on the purpose and demand for use, the buyer decides to search for real estate with an appropriate area. In particular, the land with extensive frontage area and depth, ensuring 
European Journal of Business and Innovation Research

Vol.8, No.4.pp. 16-28, July 2020

Published by ECRTD-UK

Print ISSN: 2053-4019(Print), Online ISSN: 2053-4027(Online)

the square criteria without distortion or deformation, will often be valued higher than the unequal land plots (Y1lmazel, S, 2017).

Soil characteristics: Depending on the purpose of use, and the underground will determine different prices. For example, the soft, fertile areas are often suitable for agricultural purposes, so the value is not as high as the areas with moderate hard soil, which is not too sweet, favorable for housing construction (Grissom T, 2017). The surrounding environment and nature: For areas that are frequently hit by natural disasters or environmental pollution, much noise will have a lower real estate price than areas with natural conditions and a stable environment. Therefore, the following hypothesis built.

Hypothesis H1: Natural factor has a positive impact on the real estate values of real estate in Ho Chi Minh City.

\section{Economic factor (EF)}

The level of economic development is a macroeconomic factor that determines the level, scale, and completeness of the real estate market. When the economy develops at a high standard with diverse purposes and skills in land use, the type of real estate goods will be plentiful, leading to the need to transfer real estate between entities in the economy (Jin Y, 2013). The emergence of new industries, new businesses, and new construction techniques has also led to the need to convert and transfer real estate between entities and between economic sectors. Therefore, The trend of industrialization and modernization of the economy and the real estate market also has motivation and room to develop quickly. Besides, the development of other markets, typically the financial market, also requires the growth of the real estate market (Ying Li Yap, 2019).

Real estate investment is not only concerned about utilities or the ability to meet demand. Today, buyers are more concerned about development potential and profitability in the future. Therefore, when considering economic factors, investors should not ignore core factors such as:

Profitability: The annual income from real estate will have a meaningful impact on the value of that property. That is, if you buy the property for business, for rent or for resale, the profit gained from that high or low will affect its actual value at the time of sale (Kigege A. M, 2018).

Connection facilities: Including electricity, water, sanitation, air conditioning, communication. The more complete the system of facilities, the better the quality, the higher the value of the real estate. Therefore, the following hypothesis built.

Hypothesis H2: Economic factor has a positive impact on the real estate values of real estate in Ho Chi Minh City.

\section{Market factor (MF)}

Market factors will consider the usefulness of real estate, including actual use-value and potential use-value in real estate products. Besides, investors need to find additional market demand, assess whether the actual supply-demand level is different. Buyers can compare real estate, such as the demand for apartment real estate is soaring, the need for land real estate will decrease, and vice versa (Lin, S. W, 2013). When demand is lower than supply, real estate prices tend to fall. 
European Journal of Business and Innovation Research

Vol.8, No.4.pp. 16-28, July 2020

Published by ECRTD-UK

Print ISSN: 2053-4019(Print), Online ISSN: 2053-4027(Online)

However, the price also depends on many other factors such as those arising from market imperfections such as "monopoly," "speculation," "unfair competition." Factors stemming from the State's intervention such as the State's investment in upgrading the infrastructure of residential areas (roads, water supply, and drainage, electricity supply), increasing or exempting Taxes for enterprises dealing in real estate, applying the auction of state-owned real estate assets. housing policies for low-income people; factors are originating from the psychology and habits of the people such as not wanting to sell real estate left by their ancestors, or not like living in apartments, or the desire to have houses located on national highways, provincial roads (Marija Burinskiene, 2017). Therefore, the following hypothesis built.

Hypothesis H3: Market factor has a positive impact on the real estate values of real estate in Ho Chi Minh City.

\section{Legal factor (LF)}

Buyers should consider the documents proving land use rights, house ownership, construction permits, real estate mortgages, the status of disputes over land use rights. Help real estate liquidated and transparent for buying activities and sell. The change in the State and local authorities can have an impact on the real estate market in general and investment in the real estate sector in particular (Ong T. S, 2014). Detail: Policies that have indirect effects such as encouragement of external financing in the locality may increase the demand for real estate, thereby increasing property prices. Regulations on construction and architecture associated with real estate (Pyhrr, S, 2015). Restrictions on land use rights, ownership of houses and other construction works related to real estate: rental status, real estate mortgage, the status of dispute rights land use, house ownership, restrictions on shared ownership (for example, houses built in areas where the runway is up and down cannot be more than three stories high.). Therefore, the following hypothesis developed.

Hypothesis H4: The legal factor has a positive impact on the real estate values of real estate in Ho Chi Minh City.

\section{Social factor (SF)}

Real estate value is also heavily influenced by population density, service quality, utilities on health and education, regional security. When the population density in the region increases, the balance between supply and demand broken, so real estate prices in that area will increase rapidly (Selim, S, 2016). Besides, in places where the quality of health services, education, and security issues is good, real estate is also much sought after, thereby increasing the value of the real estate. Social factors also have a significant impact on real estate values. An area where population density suddenly increases due to the growth of the mechanical population; increases the value of real estate there will increase due to the disruption of the supply-demand balance. On the other hand, other factors in the region, such as the quality of health services, education, educational level, security issues, and habits of the people in the area, also affect the value of the real estate (Sutton, 2013). People live in real estate, health status, occupation and employment status, emotional relationships of family and society of people living together. Therefore, the following hypothesis built. 
The authors support the research model for various factors affecting the real estate values of real estate in Ho Chi Minh City.

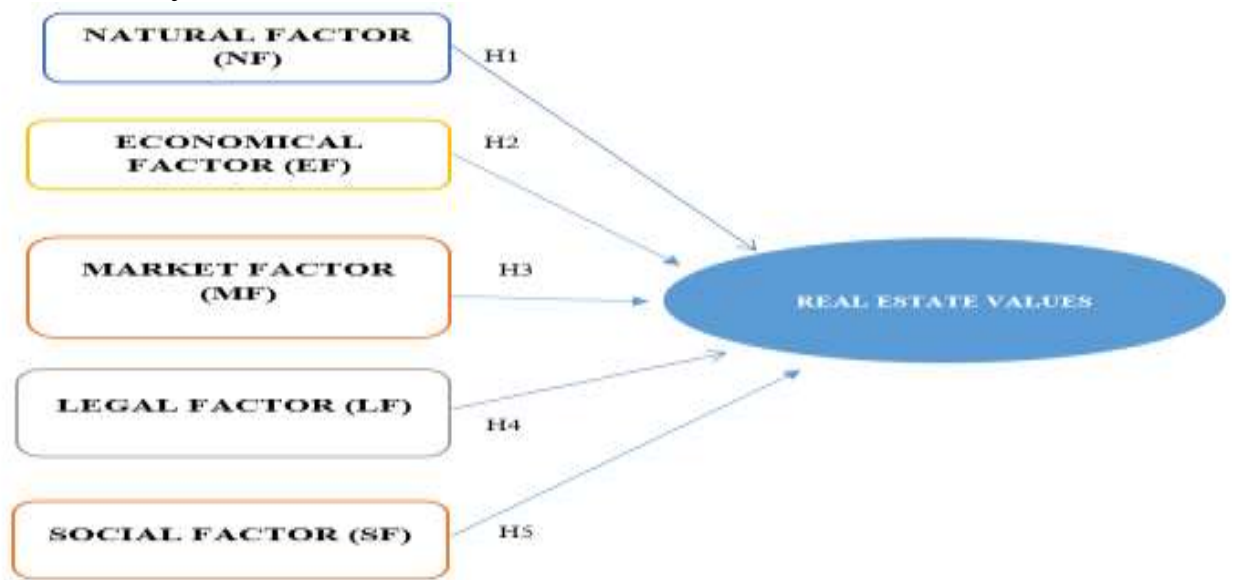

Figure 1

(Source: Authors proposed)

Research Model For Factorise Affection The Real Estate Values Of Real Estate In Ho Chi Minh City

\section{METHODS OF RESEARCH}

The authors support the research process for various factors affecting the real estate values of real estate in Ho Chi Minh City.
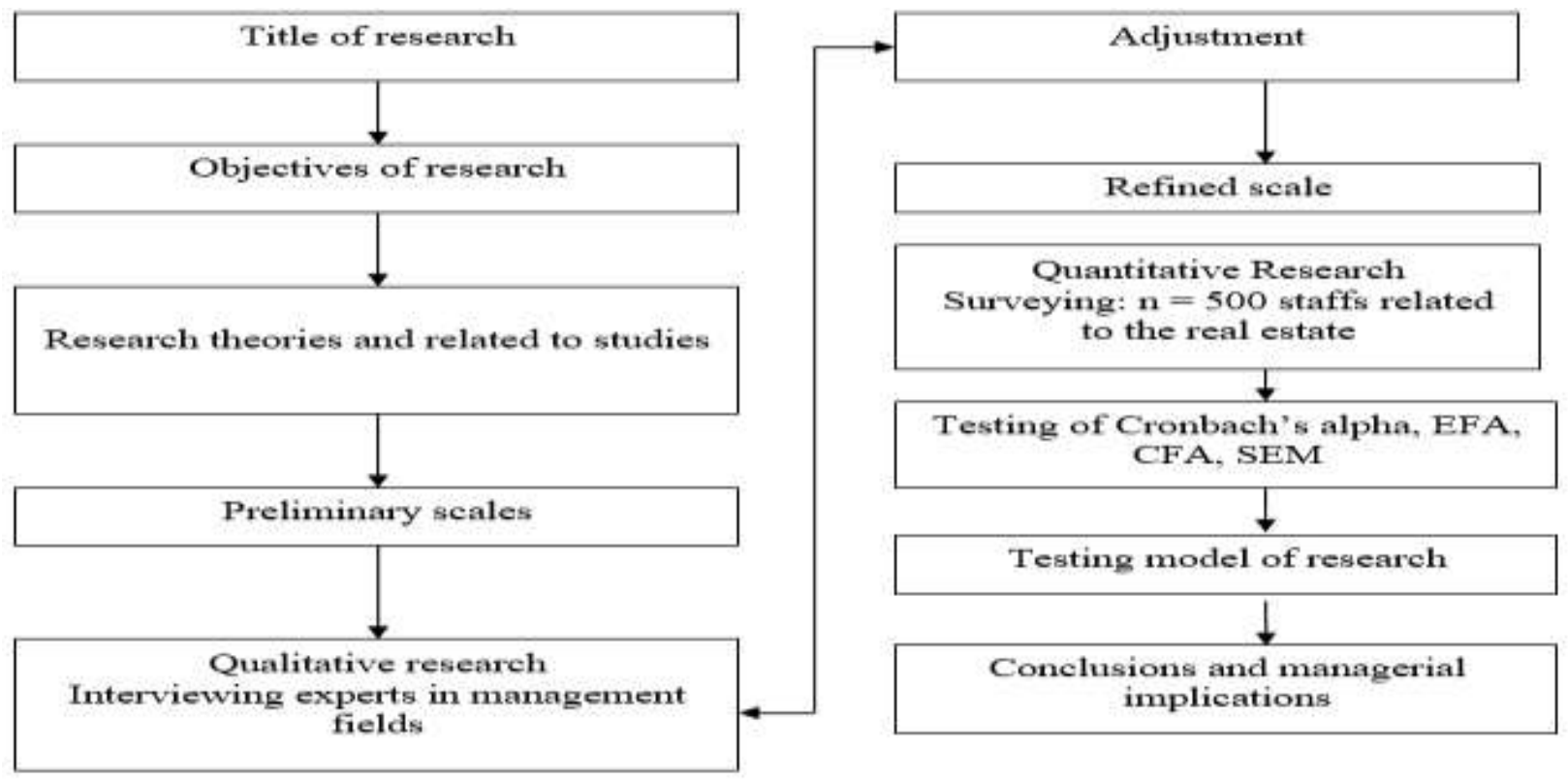

Figure 2: Research Processing For Factors Affecting The Real Estate Values Of Real Estate In Ho Chi Minh City 
European Journal of Business and Innovation Research

Vol.8, No.4.pp. 16-28, July 2020

Published by ECRTD-UK

Print ISSN: 2053-4019(Print), Online ISSN: 2053-4027(Online)

Figure 2 showed that various factors affecting the real estate values of real estate in Ho Chi Minh City having many steps following:

- The authors identified the title of research: It is one of the first steps in developing the real estate values of real estate in Ho Chi Minh City. The problem of research usually chosen through experience and accumulated knowledge.

- The authors identified the objectives of the

Research. The authors found various factors the real estate values of real estate in Ho Chi Minh City.

- After study objectives, the authors identified the research theories and relevant studies.

- Preliminary scales. The authors built initial scales and applied the expert methodology to improve the scale and the questionnaire. The results surveyed 30 experts who showed that all factors the real estate values of real estate in Ho Chi Minh City.

- Qualitative research interviewing experts in management fields. The authors had an adjustment and refined scale by testing a reliability scale with Cronbach's Alpha coefficient and exploratory factor analysis.

- Adjustment: The authors applied quantitative research to interview 150 staff members for 30 companies related to real estate in Ho Chi Minh City. Each company surveyed five staffs. The research results built a questionnaire for quantitative research $(\mathrm{n}=500 \mathrm{staffs})$.

- Refined scale: the authors had preliminary adjustment scales and tested a reliability scale with Cronbach's Alpha coefficient and exploratory factor analysis for a sample of 150 staffs.

- Quantitative Research surveying: $n=500$ staffs related to the real estate by questionnaires and tested a reliability scale with Cronbach's Alpha coefficient and exploratory factor analysis. There are 24 items and 485 samples processed and data collected from January 2020 to May 2020 at 50 companies related to real estate in Ho Chi Minh City. The authors had a simple random sampling technique and spent 35 minutes on a survey. All data collected from the questionnaire coded, processed by SPSS 20.0 and Amos.

- Testing of Cronbach's Alpha, EFA, CFA, SEM: the authors tested Cronbach's Alpha, EFA, CFA, SEM. This method based on the eigenvalue, the appropriate factorial analysis, and the observed variables in the whole which are correlated when Average Variance Extracted is $>50 \%$, the KMO coefficient is within 0.5 to 1 , Sig coefficient $\leq 5 \%$, the loading factors of all observed variables are $>0.5$. Also, the authors tested exploratory factor analyses (EFA) were performed (Hair, Anderson, Tatham, \& Black, 1998).

- Testing model of research: the authors tested the model of research: the authors specified the number of factors required in the data and which measured variable is related to which latent 
European Journal of Business and Innovation Research

Vol.8, No.4.pp. 16-28, July 2020

Published by ECRTD-UK

Print ISSN: 2053-4019(Print), Online ISSN: 2053-4027(Online)

variable. Confirmatory factor analysis (CFA) is a tool used to confirm or reject the measurement theory. The purpose of CFA helps to clarify: (1) Unilaterality, (2) Reliability of scale, (3) Convergence value, and (4) Difference value. A research model is considered relevant to market data if Chi-square testing is $\mathrm{P}$-value $>5 \%$; CMIN/df $\leq 2$, some cases CMIN/df maybe $\leq 3$ or $<5$ (Hair, Anderson, Tatham, \& Black, 1998); GFI, TLI, CFI $\geq 0.9$. However, according to recent authors' opinions, GFI is still acceptable when it is greater than 0.8 ; RMSEA $\leq 0.08$. Apart from the above criteria, the test results must also ensure the synthetic reliability > 0.6; Average Variance Extracted must be greater than 0.5 (Hair, Anderson, Tatham, \& Black, 1998).

- Conclusions and managerial implications: the authors had findings of the research, and the authors had recommendations.

\section{RESEARCH RESULTS}

The authors support the scale reliability tests for various factors affecting the real estate values of real estate in Ho Chi Minh City.

\begin{tabular}{|c|c|c|}
\hline \multicolumn{3}{|c|}{$\begin{array}{c}\text { Table } 1 \\
\text { THE SCALE RELIABILITY TESTS FOR VARIOUS FACTORS AFFECTING THE REAL ESTATE } \\
\text { VALUES OF REAL ESTATE IN HO CHI MINH CITY }\end{array}$} \\
\hline Items & Content & $\begin{array}{l}\text { Cronbach's } \\
\text { Alpha if } \\
\text { Item Deleted }\end{array}$ \\
\hline NF1 & Real estate is in the center of an urban area relative location & .939 \\
\hline NF2 & Deformation will often be valued higher than the unequal land plots & .919 \\
\hline NF3 & The surrounding environment and nature & .910 \\
\hline NF4 & There are soil characteristics & .921 \\
\hline \multicolumn{2}{|r|}{ Cronbach's Alpha for natural factor (NF) } & 0.941 \\
\hline EF1 & Economic development requires the development of the real estate market & .939 \\
\hline EF2 & the real estate market also has motivation and room to develop & .960 \\
\hline EF3 & Real estate investment is not only concerned about utilities or ability to meet demand & .956 \\
\hline EF4 & $\begin{array}{l}\text { Connection facilities: Including electricity, water, sanitation, air conditioning, } \\
\text { communication }\end{array}$ & .937 \\
\hline \multicolumn{2}{|r|}{ Cronbach's Alpha for economic factor (EF) } & 0.961 \\
\hline MF1 & Market factors here will consider the usefulness of real estate & .815 \\
\hline MF2 & Investors need to consider additional market demand & .822 \\
\hline MF3 & $\begin{array}{l}\text { The price also depends on many other factors such as those arising from market } \\
\text { imperfections such as monopoly }\end{array}$ & .851 \\
\hline MF4 & The desire is to have houses located on national highways & .810 \\
\hline \multicolumn{2}{|r|}{ Cronbach's Alpha for market factor (MF) } & 0.862 \\
\hline LF1 & Buyers should consider the documents proving land use rights & .932 \\
\hline LF2 & $\begin{array}{l}\text { The change in the State and local authorities policies can have impacts on the operation } \\
\text { of the real estate market }\end{array}$ & .953 \\
\hline LF3 & External investment in the locality may increase the demand for real estate & .954 \\
\hline LF4 & Ownership of houses and other construction works associated with real estate & .936 \\
\hline \multicolumn{2}{|r|}{ Cronbach's Alpha for legal factor (LF) } & 0.958 \\
\hline SF1 & Real estate value is also heavily influenced by population density & .929 \\
\hline SF2 & Service quality, utilities on health and education, regional security & .953 \\
\hline SF3 & The quality of health services, education, and security issues is good & .947 \\
\hline
\end{tabular}


European Journal of Business and Innovation Research

Vol.8, No.4.pp. 16-28, July 2020

Published by ECRTD-UK

Print ISSN: 2053-4019(Print), Online ISSN: 2053-4027(Online)

\begin{tabular}{|c|c|c|}
\hline SF4 & Emotional relationships of family and society of people living together & .930 \\
\hline \multicolumn{2}{|r|}{ Cronbach's Alpha for social factor (SF) } & 0.954 \\
\hline REV1 & Natural factor affecting the real estate values of real estate in Ho Chi Minh City & .854 \\
\hline REV2 & Economic factor affecting the real estate values of real estate in Ho Chi Minh City & .794 \\
\hline REV3 & Market factor affecting the real estate values of real estate in Ho Chi Minh City & .858 \\
\hline REV4 & Legal and Social factor affecting the real estate values of real estate in Ho Chi Minh City & .805 \\
\hline & Cronbach's Alpha for real estate values (REV) & 0.867 \\
\hline
\end{tabular}

(Source: The authors' collecting data and SPSS 20.0)

Table 1 showed that factors of the real estate values of real estate in Ho Chi Minh City had 24 variables surveyed corrected item-total correlation greater than 0.3 and Cronbach's Alpha if Item deleted greater than 0.6. Cronbach's Alpha for natural factor (NF) is 0.941 ; economical factor (EF) is 0.961 ; market factor (MF) is 0.862 ; legal factor (LF) is 0.958 ; social factor (SF) is 0.954 ; and real estate values (REV) is 0.867. All of the components have Cronbach's Alpha more than 0.6.

\begin{tabular}{|c|c|c|c|c|c|c|c|}
\hline \multicolumn{7}{|c|}{ TOTAL VARIANCE EXPLAINED } \\
\hline \multirow{2}{*}{ Component } & $\begin{array}{c}\text { Extraction Sums of Squared } \\
\text { Loadings }\end{array}$ & $\begin{array}{c}\text { Rotation Sums of } \\
\text { Squared Loadings }\end{array}$ \\
\cline { 2 - 8 } & Total & $\begin{array}{c}\text { Cumulative } \\
\%\end{array}$ & Total & $\begin{array}{c}\text { \% of } \\
\text { Variance }\end{array}$ & $\begin{array}{c}\text { Cumulative } \\
\%\end{array}$ & Total \\
\hline 1 & 6.749 & 28.122 & 28.122 & 6.749 & 28.122 & 28.122 & 3.885 \\
\hline 2 & 3.773 & 15.723 & 43.844 & 3.773 & 15.723 & 43.844 & 5.038 \\
\hline 3 & 3.514 & 14.644 & 58.488 & 3.514 & 14.644 & 58.488 & 3.643 \\
\hline 4 & 2.587 & 10.779 & 69.267 & 2.587 & 10.779 & 69.267 & 5.067 \\
\hline 5 & 1.718 & 7.160 & 76.427 & 1.718 & 7.160 & 76.427 & 4.575 \\
\hline 6 & 1.530 & 6.377 & 82.804 & 1.530 & 6.377 & 82.804 & 2.995 \\
\hline$\ldots$ & $\ldots$ & $\ldots$ & $\ldots$ & & & & \\
\hline 24 & .032 & .135 & 100.000 & & & & \\
\hline \multicolumn{7}{|c|}{ Kaiser-Meyer-Olkin Measure of Sampling Adequacy is $0.823 ;$ Sig is 0.000.} \\
\hline
\end{tabular}

(Source: The authors' collecting data and SPSS 20.0) Table 2 showed that extraction sums of squared loadings of cumulative $\%$ are $82.804 \%(>60 \%)$, and initial eigenvalues are $1.530(>1.0)$. The KMO coefficient is 0.823 , and the level of significance ( $\mathrm{Sig}$ ) is 0.000 . This result is suitable for the next step. 
European Journal of Business and Innovation Research

Vol.8, No.4.pp. 16-28, July 2020

Published by ECRTD-UK

Print ISSN: 2053-4019(Print), Online ISSN: 2053-4027(Online)

\begin{tabular}{|c|c|c|c|c|c|c|}
\hline \multicolumn{7}{|c|}{$\begin{array}{c}\text { Table } 3 \\
\text { KMO AND BARTLETT'S TEST FOR VARIOUS FACTORS AFFECTING THE REAL } \\
\text { ESTATE VALUES OF REAL ESTATE IN HO CHI MINH CITY }\end{array}$} \\
\hline \multirow{2}{*}{ Code } & \multicolumn{6}{|c|}{ Component } \\
\hline & 1 & 2 & 3 & 4 & 5 & 6 \\
\hline EF4 & .970 & & & & & \\
\hline EF1 & .965 & & & & & \\
\hline EF3 & .929 & & & & & \\
\hline EF2 & .919 & & & & & \\
\hline SF1 & & .960 & & & & \\
\hline SF4 & & .950 & & & & \\
\hline SF2 & & .939 & & & & \\
\hline SF3 & & .881 & & & & \\
\hline LF1 & & & .959 & & & \\
\hline LF4 & & & .952 & & & \\
\hline LF2 & & & .931 & & & \\
\hline LF3 & & & .926 & & & \\
\hline NF3 & & & & .996 & & \\
\hline NF4 & & & & .975 & & \\
\hline NF2 & & & & .881 & & \\
\hline NF1 & & & & .766 & & \\
\hline REV4 & & & & & .894 & \\
\hline REV2 & & & & & .880 & \\
\hline REV1 & & & & & .845 & \\
\hline REV3 & & & & & .751 & \\
\hline MF4 & & & & & & .872 \\
\hline MF1 & & & & & & .861 \\
\hline MF2 & & & & & & .836 \\
\hline MF3 & & & & & & .800 \\
\hline
\end{tabular}

(Source: The authors' collecting data and SPSS 20.0)

Table 3 showed that there are six components. Extraction sums of squared loadings coefficient are $82.804 \%$, and significance ( $\mathrm{Sig}$ ) is 0.000 .

\begin{tabular}{|l|l|l|c|c|c|c|c|c|}
\hline \multicolumn{7}{|c|}{ COEFFICIENTS FROM 4 } \\
\hline \multicolumn{2}{|c|}{ Relationships } & Coefficient & $\begin{array}{c}\text { Standardized } \\
\text { Coefficient }\end{array}$ & S.E & C.R. & P & Conclusion \\
\hline $\begin{array}{l}\text { Real estate } \\
\text { values }\end{array}$ & $<---$ & $\begin{array}{l}\text { Economical } \\
\text { factor }\end{array}$ & .067 & .137 & .020 & 3.258 & .001 & $\begin{array}{c}\text { H2: } \\
\text { Supported }\end{array}$ \\
\hline $\begin{array}{l}\text { Real estate } \\
\text { values }\end{array}$ & $<---$ & $\begin{array}{l}\text { Natural } \\
\text { factor }\end{array}$ & .181 & .340 & .031 & 5.780 & $* * *$ & $\begin{array}{c}\text { H1: } \\
\text { Supported }\end{array}$ \\
\hline $\begin{array}{l}\text { Real estate } \\
\text { values }\end{array}$ & $<---$ & $\begin{array}{l}\text { Market } \\
\text { factor }\end{array}$ & .075 & .120 & .025 & 2.972 & .003 & $\begin{array}{c}\text { H3: } \\
\text { Supported }\end{array}$ \\
\hline $\begin{array}{l}\text { Real estate } \\
\text { values }\end{array}$ & $<---$ & $\begin{array}{l}\text { Social } \\
\text { factor }\end{array}$ & .109 & .234 & .025 & 4.461 & $* * *$ & $\begin{array}{c}\text { H5: } \\
\text { Supported }\end{array}$ \\
\hline $\begin{array}{l}\text { Real estate } \\
\text { values }\end{array}$ & $<---$ & Legal factor & .062 & .124 & .021 & 3.027 & .002 & $\begin{array}{c}\text { H4: } \\
\text { Supported }\end{array}$ \\
\hline
\end{tabular}

Note: ***Significant at 1.0 percent (All t-tests are one-tailed) 
(Source: The authors' collecting data, SPSS 20.0 and Amos)

Table 4 showed that column "P" $<0.01$ with significance level 0.01 and column "Conclusion" following:

H1: supported: Natural factor has a positive impact on the real estate values of real estate in Ho Chi Minh City with significance level 0.01.

H2: supported: Economic factor has a positive impact on the real estate values of real estate in Ho Chi Minh City with significance level 0.01.

H3: supported: Market factor has a positive impact on the real estate values of real estate in Ho Chi Minh City with significance level 0.01.

H4: supported: Legal factor has a positive impact on the real estate values of real estate in Ho Chi Minh City with significance level 0.01.

H5: supported: Social factor has a positive impact on the real estate values of real estate in Ho Chi Minh City with significance level 0.01.

This result showed that five factors: natural factor (NF); economic factor (EF); market factor (MF), legal factor (LF; social factor (SF), and real estate values (REV).

They are affecting the real estate values of real estate in Ho Chi Minh City with a significance level of 0.01 .

Besides, Chi-square $=606.779 ; \mathrm{df}=224 ; \mathrm{p}=0.000 ;$ Chi-square $/ \mathrm{df}=2.709 ; \mathrm{GFI}=0.910 ;$ $\mathrm{TLI}=0.960 ; \mathrm{CFI}=0.968 ; \mathrm{RMSEA}=0.059$.

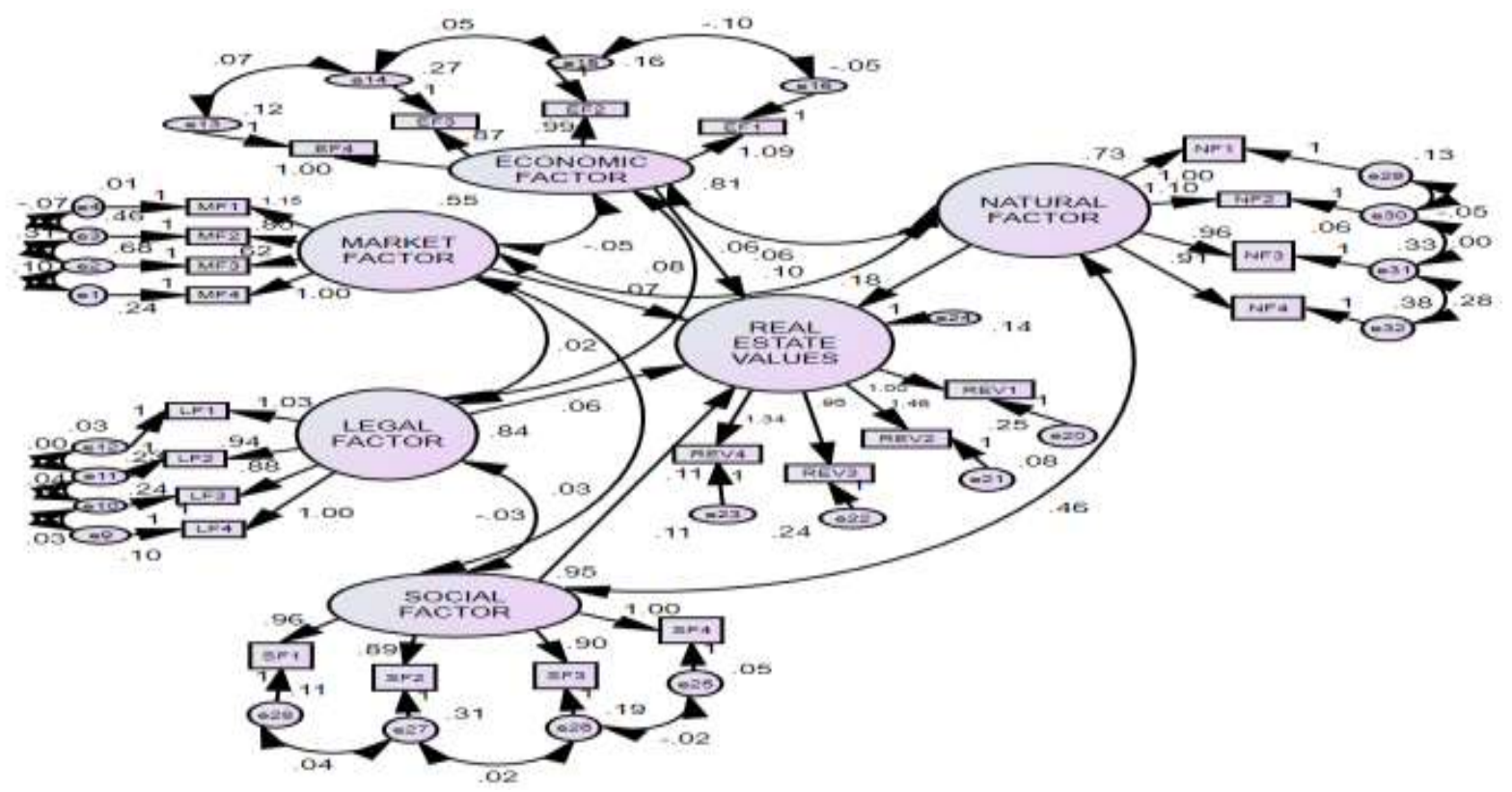

(Source: The authors' collecting data and Amos) Figure 3: The Structural Model Showing the Structural Linkage Between Components 
European Journal of Business and Innovation Research

Vol.8, No.4.pp. 16-28, July 2020

Published by ECRTD-UK

Print ISSN: 2053-4019(Print), Online ISSN: 2053-4027(Online)

\section{CONCLUSIONS AND MANAGERIAL IMPLICATIONS}

\section{Conclusions}

Real estate plays a critical role in the development of the economy, contributing to promoting investment capital mobilization, promoting production and development. This factor is increasing state budget revenues, and expanding markets, contributing to socio-economic stability. The authors surveyed 500 staffs who are working for real estate companies in HCMC. This paper used a simple random sampling technique, tested Cronbach's Alpha, the exploratory factor analysis, and Structural Equation Modelling (SEM). The paper used a questionnaire on a 5-point Likert scale. Finally, five factors affecting real estate values of real estate in Ho Chi Minh City (HCMC) with a significance level of 0.01. Based on the things as mentioned above, the authors had managerial implications following:

\section{Managerial implications}

The managerial implication for natural factor $(\boldsymbol{\beta}=\mathbf{0 . 3 4 0})$ had a positive impact on the real estate values of real estate in Ho Chi Minh City with significance level 0.01. Ho Chi Minh City needs to develop green-smart urban development is a general trend and has become a particular concern of nations, for the practical benefits of urban governance and the improvement of urban quality, especially in the context of Current 4.0 networks. Besides, the city government has also established an international cooperation platform with domestic and foreign organizations with experience in green and smart infrastructure construction such as South Korea and Singapore through models such as smart cities, green cities, livable Cities, eco-city low-carbon City.

The managerial implication for social factor $(\boldsymbol{\beta}=\mathbf{0 . 2 3 4})$ had a positive impact on the real estate values of real estate in Ho Chi Minh City with significance level 0.01. Ho Chi Minh City needs to invest some smart transport applications that bring high utilities such as bus journey monitoring, traffic surveillance cameras, traffic signal control systems, the establishment of control centers, and concentrated traffic. At the same time, HCMC has deployed IT applications in the field of the environment, such as automatic water source monitoring on drinking water standards to report to the treatment center when necessary, monitoring the warning wastewater system. Early pollution indicator to handle when needed.

The managerial implication for the economic factor $(\boldsymbol{\beta}=\mathbf{0 . 1 3 7})$ had a positive impact on the real estate values of real estate in Ho Chi Minh City with a significance level of 0.01. The City also needs to promote the digitization of businesses' resources quickly, complete the digital database of economic sectors, infrastructure and deploy intelligent governance in enterprises and state management agencies, developing Smart city implementation and actively implementing public investment of the City. The City will quickly support and promote the healthy real estate market, overcome the current great challenge, support, and encourage creative startup programs.

The managerial implication for legal factor $(\boldsymbol{\beta}=\mathbf{0 . 1 2 4})$ had a positive impact on the real estate values of real estate in Ho Chi Minh City with a significance level of 0.01. At the same time, Ho Chi Minh City proposes some solutions, such as an Overall review of investor selection 
European Journal of Business and Innovation Research

Vol.8, No.4.pp. 16-28, July 2020

Published by ECRTD-UK

Print ISSN: 2053-4019(Print), Online ISSN: 2053-4027(Online)

procedures. Investment procedures, construction management projects such as construction investment preparation, site clearance compensation, land allocation, appraisal, approval of planning, projects, environmental impact assessment to be clear in the implementation process, reducing procedures, time for implementation of administrative procedures to create ventilation, contributing to attracting invest, accelerate the implementation of projects.

The managerial implication for market factor $(\boldsymbol{\beta}=\mathbf{0 . 1 2 0})$ had a positive impact on the real estate values of real estate in Ho Chi Minh City with significance level 0.01. The State flexibly and effectively uses tax, credit, and planning-planning tools to regulate the real estate market. The State continues creating a legal framework adapting to market principles is the most important factor to form and develop the real estate market, which regulates fundamental issues such as Structure of ownership relations, property ownership, real estate, scope, subject of real estate transactions, procedures, contracts, and transaction execution measures. The State continues creating conditions for the market to decide real estate prices on the principle of competition. If well-managed land prices will prevent sudden price increases, avoid speculation land and contribute to the construction of the real estate market publicly, transparently and objectively.

\section{REFERENCES}

Clapp, J.M. (2018). The influence of economic variables on local house price dynamics. Journal of Urban Economics, 36(2), 161-183.

Filiz Ersoz (2018). Research on factors affecting real estate values by data mining. Baltic Journal of Real Estate Economics and Construction Management, 6(1), 220-239.

Golob, K. (2016). Analysis of Impact Factors on the Real Estate Market: Case Slovenia. Journal of Business Research, 58(3), 293-300.

Grissom, T. (2017). A multiple index analysis of real estate cycles and structural change. Journal of Real Estate Research, 8(2), 97-130.

Hair, J., Anderson, R., Tatham, R., \& Black, W. (1998). Multivariate Data Analysis with Readings. US: Prentice-Hall: Upper Saddle River, NJ, USA.

Jin Y. (2013). Residential investment and house prices in a multi-sector monetary business cycle model. Journal of housing economics, 13(2), 268-286.

Kigege A. M. (2018). Factors influencing real estate property value - a survey of real estate in Meru Municipality, Kenya. Journal of economics and sustainable development, 2(4), 3454.

Lin, S. W. (2013). Impact of government and industrial agglomeration on industrial land prices: A Taiwanese case study. Journal of real estate research, 23(2), 179-200.

Marija Burinskiene (2017). Models of factors influencing real estate values. International Journal of Strategic Property Management, 8(3), 163-176.

Ong T. S. (2014). Factors affecting the value of housing in Malaysia. Journal of emerging issues in economics, finance, and banking, 3(1), 414-429.

Pyhrr, S. (2015). Real estate cycles and their strategic implications for investors and portfolio managers in the global economy. Journal of real estate research, 18(2), 7-27.

Selim, S. (2016). The determinant of House Price in Turkey: A Hedonic Regression Model. Electronic Journal of Map Technologies, 4(3), 23-38. 
Print ISSN: 2053-4019(Print), Online ISSN: 2053-4027(Online)

Sutton (2013). Explaining changes in house prices. European Economic Review, 43(1), 755-766. Yihong (2016). A Study on the Influence Factors of Real Estate Prices Based on Econometric Model: A Case of Wuhan. Journal of Economic Perspectives, 3(2), 55-65.

Y1lmazel, S. (2017). Analysis of Apartments for Sale in Turkey Based on City and Region by Using Big Data Technologies. The Sakarya Journal of Economics, 6(3), 1-21.

Ying Li Yap (2019). Quality management in real estate industries. International journal of scientific \& technology research, 8(12), 96-107. 